\title{
EDITORIAL
}

\section{A IMPORTÂNCIA DE SER MEMBRO DO CBC}

\author{
Fares Rahal \\ Professor Titular. Livre-Docente de Clínica Cirúrgica \\ da Faculdade de Ciências Médicas da Santa \\ Casa de São Paulo
}

Não reconheço nenhum título associativo mais importante aos cirurgiões do nosso Brasil do que pertencer ao quadro do Colégio Brasileiro de Cirurgiões.

Fundado em 1929, no Rio de Janeiro, por um grupo de cirurgiões brilhantes, que não cito para não cometer nenhuma injustiça ou ser omisso, o CBC ultrapassou todas as expectativas dos seus idealizadores.

Sua significação se desenha na pujança atual e nos seus desígnios:

1. Agregar, defender e postular posições ética e cientificamente sólidas de todos os seus membros sem nenhum laivo de corporativismo.

2. Congregar cirurgiões nos vários rincões do país, graças a seu Diretório Central, seus Capítulos e suas Regionais, ministrando cursos de atualização e conclaves sobre os mais variados temas, exercendo a importantíssima função de qualquer associação que se preze: ensinar e atualizar.

3. Realizar, a cada dois anos, o maior congresso de cirurgia do nosso país, sempre com o objetivo de atualização do médico nas mais variadas especialidades da arte da cirurgia.

4. O Colégio Brasileiro de Cirurgiões é intransigente na defesa da residência médica em nosso país. Destaca-se na luta pela residência médica lato sensu objetivando sempre sua melhora funcional e científica, e defendendo a idéia de que o residente não é mero "tocador" de serviço. Para isso, sua Comissão de Residência Médica, periodicamente, visita os hospitais para analisar suas residências dando-lhes ou não seu aval.

5. Exerce destacada atuação na defesa do profissional médico, como antes referido, sem corporativismo, mas defendendo-o principalmente dos descalabros dos convênios médicos, questionando, discutindo e evitando com esta defesa a desagregação da classe e, por conseqüência, queda dos seus valores científico e ético.

6. Mantém intercâmbio com várias associações de classe. Com a Associação Médica Brasileira tem vinculação efetiva realizando concursos para obtenção do título de especialista em cirurgia geral.

7. Com a Academia Brasileira de Medicina, tem permuta permanente. Vários "cebeceanos" são membros dessa veneranda instituição.

8. Edita a revista CBC em ininterrupta atividade há 27 anos. Distribuída a todos os seus membros, tem um Corpo Editorial de altíssima qualidade, que analisa para aprovação os artigos enviados. Publicados, propiciam atualização a todos os cirurgiões. Em inúmeras oportunidades o Colégio e sua Revista têm programado várias reuniões com profissionais altamente categorizados para estabelecer "consenso de conduta" para as mais variadas doenças de tratamento cirúrgico, tempestivamente, vindas a lume.

A maioria dos grandes nomes da cirurgia nacional são ou membros associados titulares ou eméritos do Colégio Brasileiro de Cirurgiões. Participar do Colégio é uma honraria que envaidece e enobrece o cirurgião. O Colégio Brasileiro de Cirurgiões, sem dúvida alguma, é partícipe importante da história da cirurgia brasileira. 